\title{
First report of Pythium cucurbitacearum causing fruit rot of durian in the Philippines
}

\author{
Tamie C. Solpot ${ }^{1,2}$ (1) $\cdot$ Christian Joseph R. Cumagun ${ }^{2,3}$
}

Received: 20 May 2020 / Accepted: 20 June 2021 / Published online: 30 June 2021

(c) Società Italiana di Patologia Vegetale (S.I.Pa.V.) 2021

Keywords Fruit rot $\cdot$ Durian disease $\cdot$ Pythium - Oomycete

Durian (Durio zibethinus Murray) known as the 'king of fruits' is widely cultivated in the tropics of Asia. In September 2019, durian fruit rot was observed in Calinan, Davao City, Mindanao, Philippines ( $7^{\circ} 10.9620^{\prime} \mathrm{N} ; 125^{\circ} 25.0480$ 'E). About $10-15 \%$ of fruits in a durian orchard displayed mild to severe infections. Symptoms included small brown to grey lesions up to severe rot, with aerial white mycelial on the surface of infected fruits. Fragments of infected tissues $\left(2-3 \mathrm{~mm}^{2}\right)$ were excised from the diseased-healthy parts of fruits, disinfected with $10 \% \mathrm{NaOCl}$ for $2 \mathrm{~min}$, rinsed twice in distilled sterile water, and incubated on V8 juice agar. The colony of isolate (DDV-F4) of the pathogen was typically petaloid. Coenocytic hyphae $(6.3-11.61 \mu \mathrm{m}$ wide) had distinctive hyphal swellings. Sporangia were globose to ovoid and measured 7.3-12.1 ×5.6-10.90 $\mu \mathrm{m}$. Morphological characters suggested Pythium cucurbitacearum S. Takim (Santoso et al. 2015). To confirm the taxonomy of the organism, molecular identification was carried out. Genomic DNA was extracted and the partial ITS region was amplified with ITS1 and ITS4 primers (White et al. 1990). BLAST searches in NCBI GenBank showed that the sequence of the isolate DDV-F4 (MT280219) had $99.76 \%$ similarity to P. cucurbitacearum (KP183959) from Indonesia. To establish the pathogenicity of the pathogen, five healthy detached leaves and five matured fruits were inoculated with 5-mm-diam. mycelial plugs from 10-day-old axenic culture of isolate DDV-F4. Sterile agar plugs were

Tamie C. Solpot

tcsolpot@usm.edu.ph

1 College of Agriculture, University of Southern Mindanao, Kabacan, Cotabato, Philippines

2 Institute of Weed Science, Entomology and Plant Pathology, College of Agriculture and Food Science, University of the Philippines Los Baños College, Laguna, Philippines

3 College of Agriculture \& Life Sciences, Brigham Young University-Idaho, Rexburg, ID, USA used in the control. Two-three days after inoculation dark brown-grey circular to irregular (when they coalesced) lesions with aerial white mycelial appeared on leaves and fruits. The pathogen was successfully re-isolated from inoculated leaves and fruits. Pythium cucurbitacearum was previously reported from Indonesia (Santoso et al. 2015) and Thailand (Suksiri et al. 2018), from the soil of durian orchards. To our knowledge, this is the first report of the pathogen on durian in the Philippines.

Acknowledgements We thank Nels Hansen, Chair of the Department of Applied Plant Science, Brigham Young University Idaho, USA for editing the English language. This work was funded by the Philippine Commission on Higher Education (CHED) K-12 Transition Scholarship Grant.

\section{References}

Santoso PJ, Aryantha INP, Pancoro A, Suhandono S (2015) Identification of Pythium and Phytophthora associated with durian (Durio sp.) in Indonesia: their molecular and morphological characteristics and distribution. Asian J Plant Pathol 9 (2):59-71

Suksiri S, Laipasu P, Soytong K, Poeaim S (2018) Isolation and Identification of Phytophthora sp. and Pythium sp. from Durian Orchard in Chumphon Province, Thailand. Int J Agric Technol 14 (3):389-402

White TJ, Bruns T, Lee S, Taylor J (1990) Amplification and direct sequencing of fungal ribosomal RNA genes for phylogenetics. In: Innis MA et al (eds) PCR protocols: a guide to methods and applications. Academic Press Inc, San Diego, C.A., pp 315-322

Publisher's Note Springer Nature remains neutral with regard to jurisdictional claims in published maps and institutional affiliations. 